\title{
PERAN PEMODERASI TEKANAN WAKTU HUBUNGAN ANTARA NILAI FUNGSIONAL DAN NILAI EMOSIONAL TERHADAP NIAT BELI PRODUK FLASH SALE
}

\author{
Wiry Utami \\ Fakultas Ekonomi dan Bisnis, Universitas Bung Hatta \\ email: wiryutami@bunghatta.ac.id
}

\begin{abstract}
The research examines the role of time pressure as moderating variable to the relationship between functional value and emotional value on purchase intention on flash sale product. Data for this research were collected by online survey and administered to 150 respondents. The hypothesis testing was conducted using multiple regression analysis and hierarchical regression analysis. Finding of this indicated that functional value and emotional value have positive and significant effect on purchase intention. Time pressure has no negatively moderated the effect of functional value and emotional value on purchase intention. Keywords: functional value, emotional value, time pressure
\end{abstract}

Abstrak : Penelitian ini menguji peran tekanan waktu sebagai variabel moderasi hubungan antara nilai fungsional dan nilai emosional terhadap niat beli konsumen pada produk flash sale. Data di kumpulkan melalui survey online dengan 150 responden. Pengujian hipotesis dilakukan dengan menggunakan analisis regresi berganda dan analsisi regresi hirarki. Hasil dari penelitian menunjukan bahwa nilai fungsional dan nilai emosional berpengaruh terhadap niat beli. Tekanan waktu tidak memoderasi secara negatif pengaruh nilai fungsional dan nilai emosional terhadap niat beli.

Kata Kunci: nilai fungsional, nilai emosional, tekanan waktu

\section{A. PENDAHULAN}

Perkembangan teknologi internet membuat kehidupan semakin mudah. Beberapa perusahaan memanfaatkan internet untuk berbagai aktivitas, salah satunya untuk belanja online. Belanja online bukanlah sesuatu yang baru bagi masyarakat pada saat ini. Banyak konsumen yang memilih untuk belanja online dari pada belanja secara offline terutama pada saat pandemi sekarang. Penjual online memberikan harga yang murah, promosi yang banyak sehingga menarik minat konsumen untuk berbelanja. Kemudahan akses internet juga salah satu yang mendorong konsumen untuk berbelanja online. Hadirnya beberapa platform e-commerce menjadi pilihan bagi konsumen untuk mencari produk yang mereka perlukan.

Terdapat banyak promosi penjualan pada belanja online. Salah satu bentuk penjualan yang sangat menarik bagi konsumen adalah flash sale atau penjualan cepat. Flash sale merupakan salah satu strategi pemasaran untuk meningkatkan penjualan. Menurut Peng et al.,(2019) sebagian besar pedagang bisnis online menggunakan penjualan cepat (flash sale) untuk meningkatkan keuntungan. Flash sale merupakan bagian dari promosi penjualan yang memberikan pelanggan penawaran khusus atau diskon untuk produk tertentu dengan waktu yang dibatasi. Kannan et al., (2016) menyatakan bahwa aktivitas media sosial dan promosi flash sale mampu meningkatkan angka penjualan setelah peluncuran produk. Dengan menggunakan strategi flash sale, penjual toko online menjual produk mereka dengan diskon yang besar dan waktu yang terbatas (Vakeel et al.,2018).

Flash sale memberikan beberapa batasan seperti batasan jumlah atau kuantitas produk yang boleh dibeli dan adanya batasan waktu dengan syarat yang berbeda-beda (Cialdini, 2009). Konsumen menganggap produk flash sale tersebut langkah atau lebih murah dari harga normal, karna produk tersebut hanya membolehkan membeli produk dalam jumlah yang dibatasi. Hal ini cukup efisien untuk menarik minat konsumen untuk membeli. 
Penelitian yang menguji online flash sale masih sangat sedikit dilakukan (Vakeel et al.,2018). Flash sale berhubungan dengan nilai fungsional yang diberikan oleh produk. Ketika konsumen membeli produk yang lebih bermanfaat atau bernilai, konsumen akan lebih tertarik untuk membelinya. Selain itu, konsumen sangat memperhatikan pengalaman dalam bebelanja secara online seperti kemudahan dalam berbelanja, kenyamanan dalam berbelanja, rasa senang, komunikasi yang baik serta kepuasan dalam berbelanja online. Pengalaman berbelanja online tersebut menciptakan nilai emosional bagi konsumen. Ketika konsumen melihat produk dengan harga yang murah dari pada harga aslinya, secara emosional konsumen tertarik untuk membeli produk tersebut (Jang dan Namkung, 2009).

Beberapa platform e-commerce yang menawarkan produk flash sale juga memberikan batasan waktu untuk membeli produk. Konsumen yang gagal membeli produk dalam jangka waktu yang telah ditentukan akan merasa menyesal jika tidak membeli. Dengan adanya batasan waktu membuat konsumen lebih cepat berfikir untuk membeli (Peng et al.,2019). Hal ini memberikan tekanan waktu bagi konsumen yang berakibat terhadap niat beli konsumen. Beberapa penelitian menyebutkan bahwa tekanan waktu dapat memberikan dampak negatif bagi konsumen (Peng et al.,2019). Semakin tinggi tingkat tekanan waktu, maka keiinginan konsumen untuk membeli produk semakin lemah. Tekanan waktu juga berhubungan dengan nilai fungsional dan nilai emosional yang berdampak pada niat beli. Ketika tekanan waktu tinggi, maka akan memperlemah hubungan nilai fungsional terhadap niat beli konsumen. Begitu juga, ketika tekanan waktu tinggi juga akan memperlemah hubungan nilai emosional terhadap niat beli. Berdasarkan latar belakang diatas, peneliti tertarik untuk melakukan penelitian terkait peran tekanan waktu sebagai variabel moderasi untuk hubungan nilai fungsional dan nilai emosional terhadap niat beli konsumen pada produk flash sale.

\section{B. KAJIAN TEORI}

\subsection{Niat Beli}

Niat beli merupakan pilihan subjektif bagi konsumen untuk suatu produk. Niat beli sering digunakan untuk mengukur perilaku keinginan konsumen (Fishbein dan Ajzen, 1975). Schiffman dan Kanuk (2016) mendefinisikan keinginan untuk membeli merupakan kemungkinan konsumen untuk membeli produk tertentu, semakin tinggi niat kosumen untuk membeli maka semakin besar kemungkinan terjadi pembelian.

Schiffman dan Kanuk (2016) juga mengemukakan bahwa niat beli adalah penentuan dari seseorang konsumen untuk melakukan suatu tindakan seperti membeli sebuah produk ataupun jasa. Niat beli dapat digunakan untuk membeli suatu produk, sehingga semakin tinggi niat beli yang dimiliki individu maka akan semakin tinggi pula kesediaan untuk membeli sebuah produk.

Dodds et al., (1991) menyatakan bahwa niat beli adalah keiinginan konsumen untuk membeli suatu produk. Morwitz dan Schmittlein (1992) menunjukan bahwa kesediaan seseorang untuk membeli telah banyak digunakan sebagai prediktor perilaku konsumen. Keinginan konsumen untuk membeli suatu produk dapat dilihat dari preferensi konsumen untuk memilih suatu produk atau merek tertentu

\subsection{Nilai Fungsional}

Nilai fungsional merupakan bagian dari nilai manfaat. Nilai fungsional suatu produk atau jasa merupakan tujuan utama suatu pembelian. Nilai fungsional menyangkut kualitas, desain, daya tahan, penampilan dan keamanan (Riesz, 1980). Menurut Edwar dan Wang (2010), nilai fungsional adalah utilitas yang berasal dari kualitas yang dirasakan dan kinerja yang diharapkan dari produk seperti daya tahan, kualitas teknis dan kemudahan penggunaan.

Menurut Sweeney dan Soutar (2001), nilai fungsional terdiri dari dua dimensi yaitu harga dan kualitas. Sementara menurut Ho dan Wu (2012), terdapat tiga nilai fungsional diantaranya adalah kompetensi karakter, kesesuaian manfaat dengan harga dan kualitas 
fungsi dari barang tersebut. Ketiga aspek tersebut dinyatakan mempengaruhi niat beli konsumen. Suatu produk yang memiliki nilai fungsional yang tinggi, baik itu dari segi kualitas dan kegunaan akan menghasilkan nilai konsumsi yang tinggi sehingga mendorong intensi pembelian yang tinggi pula (Kim et al., 2009).

\subsection{Nilai Emosional}

Pembelian barang secara online menciptakan nilai emosional bagi pelanggan. Nilai emosional merupakan salah satu hal terpenting ketika belanja online. Pelanggan sangat memperhatikan pengalaman dalam berbelaja online seperti kemudahan berbelanja, keyamanan, kesenangan, komunikasi dan kepuasan diri. Hal ini menciptakan nilai emosional bagi konsumen (Jang dan Namkung, 2009). Nilai emosional mengacu pada kemampuan sikap afektif yang dapat dihasilkan pada suatu produk atau layanan. Nilai emosional diperoleh ketika produk atau layanan membangkitkan suatu perasaaan atau sikap afektif (Sweeney dan Soutar, 2001). Hal ini diperkuat oleh Hawkin dan Mothersbough (2010) menemukan bahwa nilai emosional akan mempengaruhi niat beli konsumen.

Jika konsumen mengalami perasaan positif pada saat membeli atau menggunakan suatu merek, maka merek tersebut memberikan nilai emosional. Pada intinya nilai emosional berhubungan dengan perasaan yaitu perasaan positif apa yang akan dialami konsumen pada saat membeli produk. Saidani et al., (2017) menemukan bahwa nilai emosional berpengaruh terhadap niat beli konsumen. Hal ini juga didukung oleh hasil penelitian Peng et al., (2019) yang menyatakan bahwa nilai emosional merupakan salah satu variabel yang berpengaruh terhadap niat beli.

\subsection{Tekanan Waktu}

Penelitian terkait tekanan waktu dalam berbelanja online khususnya online flash sale masih sangat sedikit dilakukan. Tekanan waktu adalah perasaan subjektif dari urgensi dan kecemasan yang dirasakan konsumen ketika berbelanja (Peng et al.,2019). Pada beberapa platform e-commerce yang menawarkan produk flash sale memberikan batasan waktu dan kuantitas dalam berbelanja online (Caldini, 2009). Selain itu, berbelanja produk flash sale juga memberikan tekanan waktu bagi konsumen. Batasan waktu berbeda dengan tekanan waktu dalam berbelanja online. Batasan waktu merupakan salah satu penyebab terjadinya time presure atau tekanan waktu. Akan tetapi dalam kontek keputusan pembelian, batasan waktu tidak selalu menghasilkan tekanan waktu. Batasan waktu tidak membuat konsumen merasa tegang dan cemas, sementara tekanan waktu membuat konsumen menjadi cemas. Svenson dan Maule (1993) menyimpulkan bahwa tekanan waktu adalah hasil dari batasan waktu dalam membuat keputusan berbelanja online.

Batasan waktu akan menyebabkan terjadinya tekanan waktu, jika pelanggan atau konsumen ingin melakukan keputusan pembelian. Sehingga konsumen tersebut harus membuat keputusan segera dengan jangka waktu tertentu. Selain itu, karna adanya tekanan waktu, menghambat konsumen untuk mengumpulkan informasi terkait produk yang akan dibeli (Easwar dan Iyer, 1989). Hal ini membuat konsumen mengambil keputusan yang buruk ketika berbelanja, sehinga berdampak negatif terhadap keputusan pembelian (Ettman, 1996). Ketika konsumen berbelanja dibawah tekanan waktu, konsumen akan merasakan stres atau cemas dan berkembang menjadi emosional yang negatif (Kocher et al.,2013; Saqib dan Chan, 2015)

Hal ini didukung oleh penelitian Inman et al.,(1997) yang menyatakan bahwa dengan adanya batasan waktu dapat memberikan signal kepada konsumen dan meningkatkan kemungkinan mereka untuk membeli produk. Namun, beberapa penelitian menunjukan bahwa ketika pembelian dibatasi oleh waktu, konsumen memberikan pandangan negatif pada proses pembelian.

\subsection{Perumusan dan Pengembangan Hipotesis \\ 2.5.1 Hubungan Nilai Fungsional dan Niat Beli}


Nilai fungsional adalah bagian dari nilai manfaat. Jika manfaat yang diterima melebihi biaya yang dikeluarkan, maka nilai tersebut positif. Nilai fungsional dari suatu produk merupakan tujuan utama konsumen untuk membeli Peng et al.,(2019). Nilai fungsional terdiri dari kualitas produk, design, kehandalan, penampilan dan keamanan suatu produk Riesz (1980). Hasil penelitian Toufani et al.,(2017) mendapatkan bahwa variabel nilai fungsional merupakan variabel yang paling berpengaruh terhadap niat beli. Selain itu pada penelitian Peng et al.,(2019) juga mendapatkan nilai fungsional berpengariuh terhadap niat beli. Jadi, semakin tinggi nilai fungsional suatu produk maka semakin besar juga keinginan konsumen untuk membeli produk. Berdasarkan penjelasan tersebut maka dapat dirumuskan hipotesis sebagai berikut:

\section{$\mathrm{H}_{1}$ : Nilai fungsional berpengaruh positif dan signifikan terhadap niat beli \\ 2.5.2 Hubungan Nilai Emosional dan Niat Beli}

Nilai emosional merupakan salah satu hal terpenting ketika bebelanja online. Konsumen sangat memperhatikan pengalaman dalam berbelanja secara online seperti kemudahan dalam berbelanja, kenyamanan dalam berbelanja, rasa senang, komunikasi yang baik serta kepuasan dalam berbelanja online. Pengalaman berbelanja online menciptakan nilai emosional bagi konsumen (Jang dan Namkung, 2009). Nilai emosional mengacu pada kemampuan sikap afektif yang dapat dihasilkan pada suatu produk atau layanan. Nilai emosional diperoleh ketika produk atau layanan membangkitkan suatu perasaaan atau sikap afektif (Sweeney dan Soutar, 2001). Semakin tinggi nilai emosional maka semakin besar keinginan konsumen untuk membeli. Berdasarkan penjelasan tersebut maka dapat dirumuskan hipotesis sebagai berikut :

\section{$\mathrm{H}_{2}$ : Nilai emosional berpengaruh positif dan signifikan terhadap niat beli}

\subsubsection{Hubungan Nilai Fungsional dan Niat Beli Dengan Tekanan Waktu Sebagai Variabel Moderasi}

Nilai fungsional menyangkut kinerja dari suatu produk. Konsumen akan membandingkan kinerja suatu produk dengan produk yang lain ketika ingin membeli suatu produk. Sebagian besar konsumen memiliki pengetahuan yang terbatas tentang kinerja suatu produk, sehingga mereka memerlukan waktu untuk mengumpulkan informasi terkait produk yang akan dibeli. Jika konsumen tidak punya banyak waktu untuk mendapatkan informasi, mereka membeli produk menggunakan informasi yang ada pada produk untuk mengambil keputusan (Krishnan et al ., (2013). Ketika konsumen menilai fungsional suatu produk di bawah tekanan waktu, mereka akan merasakan stress secara psikologis yang menyebabkan penghindaran risiko (Saqib dan Chan, 2015). Ketika konsumen melihat adanya risiko, konsumen cenderung mencari cara untuk mengurangi ketidakpastian tersebut untuk meminimalkan risiko. Hal ini dapat membuat konsumen menunda pengambilan keputusan atau meninggalkan pembelian untuk menghindari kerugian (Peng et al., 2019). Sehingga tekanan waktu berpengaruh negatif terhadap niat beli konsumen. Ketika tekanan waktu tinggi, maka akan memperlemah hubungan nilai fungsional terhadap niat beli. Berdasarkan penjelasan tersebut maka dapat dirumuskan hipotesis sebagai berikut:

\section{$H_{3}$ : Tekanan waktu memoderasi secara negatif hubungan nilai fungsional terhadap niat beli.}

\subsubsection{Hubungan Nilai Emosional dan Niat Beli DenganTekanan Waktu Sebagai Variabel Moderasi}


Nilai emosional merupakan utilitas yang berasal dari perasaan atau sifat afektif yang dihasilkan dari proses pembelian suatu produk (Chen dan Tsai, 2008). Berdasarkan penelitian sebelumnya, ketika konsumen berbelanja dibawah tekanan waktu, mereka akan menghasilkan emosi yang negatif seperti ketegangan, kecemasan dan kekhawatiran (Paola dan Gioia, 2016). Hal ini menurunkan nilai emosional yang dirasakan konsumen untuk membeli suatu produk. Batasan waktu dan batasan promosi menyebabkan terjadinya tekanan waktu yang akan berinteraksi dengan nilai emosional sehingga melemahkan niat beli konsumen. Sehingga, semakin tinggi tekanan waktu, maka akan memperlemah hubungan nilai emosional terhadap niat beli. Berdasarkan penjelasan tersebut maka dapat dirumuskan hipotesis sebagai berikut :

\section{$\mathrm{H}_{4}$ : Tekanan waktu memoderasi secara negatif hubungan nilai emosional terhadap niat beli}

\subsection{Kerangka Model Penelitian}

Berikut kerangka model penelitian dapat dilihat pada Gambar 1 dibawah ini:

\section{Gambar 1}

\section{Kerangka Penelitian}

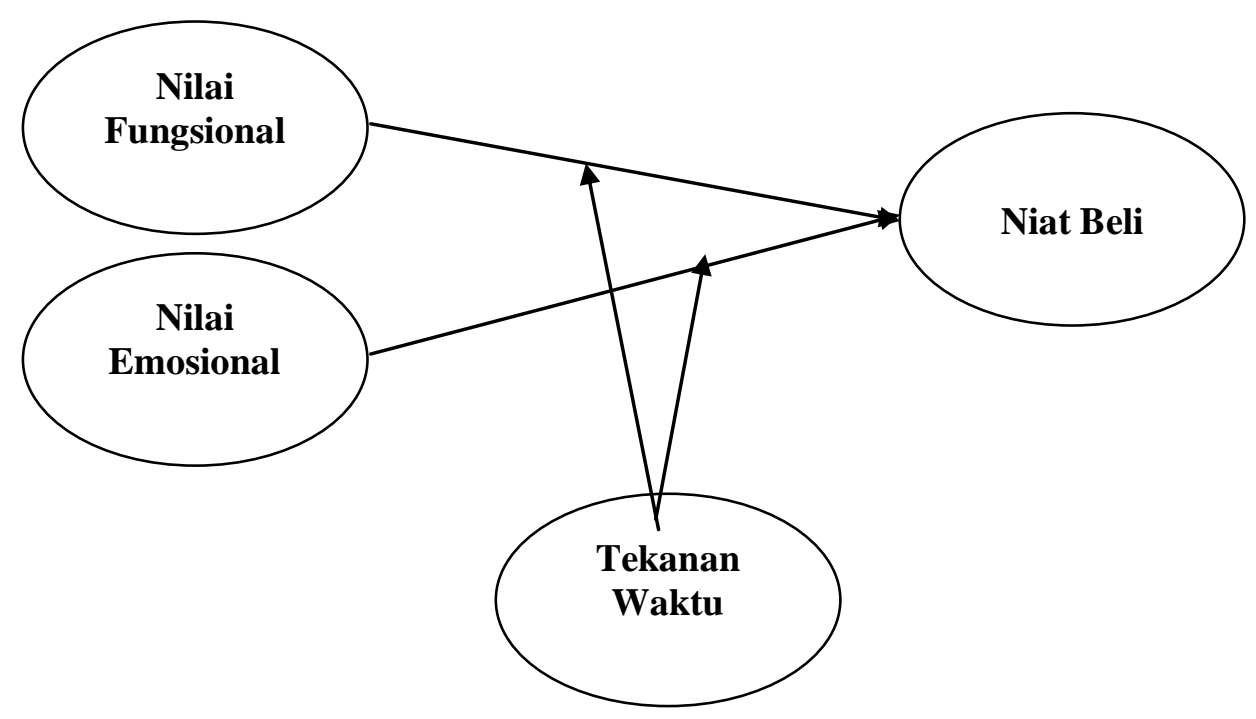

\section{METODE PENELITIAN}

\section{a. Penyampelan dan Pengumpulan Data}

Penelitian ini dilakukan untuk mengetahui peran moderasi dari tekanan waktu terhadap hubungan antara nilai fungsional dan nilai emosional terhadap niat beli produk flash sale. Penelitian ini merupakan penelitian eksplanatori yaitu penelitian yang menguji hipotesis yang ada. Metode yang digunakan dalam penelitian ini adalah metode kuantitatif dengan menggunakan metode survei. Penelitian kuantitatif adalah penelitian yang menekankan pada penggunaan pertanyaan dengan standar formal dan sebelumnya telah ditetapkan pilihan jawaban dalam kuesioner yang dibagikan kepada responden (Hair et al., 2014). Teknik pengumpulan data dengan survei ini menggunakan online survey yang mana masing-masing kuesioner diisi langsung oleh responden 
Dalam penelitian ini jumlah sampel yang digunakan 150 responden. Mayoritas responden perempuan yaitu 95 orang $(63,3 \%)$ dan laki-laki 55 orang $(36,7 \%)$. Sebagain responden memiliki rentang usia 21-25 tahun sebanyak 70 orang $(46,7 \%)$. Mayoritas responden memiliki tingkat pendidikan terakhir SMA sebanyak 83 (55,3\%). Sebagian besar responden adalah mahasiswa sebanyak 99 orang (66\%). Pengeluaran perbulan responden adalah $\mathrm{Rp} 1.000 .001$ - Rp 2.500 .000 sebanyak 68 orang (45,3\%). Perangkat elektronik yang paling sering digunakan untuk berbelanja online adalah smartphone sebanyak 145 orang $(96,7 \%)$.

\section{b. Pengukuran Variabel}

Variabel independen dalam penelitian ini adalah nilai fungsional dan nilai emosional, variabel dependen adalah niat beli, dan variabel moderasi pada penelitian ini adalah tekanan waktu. Skala pengukuran yang digunakan untuk nilai fungsional, nilai emosional, tekanan waktu dan niat beli dikembangkan oleh Peng et al.,(2019). Analisis data dalam penelitian ini dilakukan menggunakan analisis regresi berganda untuk pengujian hipotesis 1 dan hipotesis 2. Sementara untuk hipotesis 3 dan hipotesis 4 (uji moderasi) menggunakan analisis regresi hirarki.

Tabel 1

Definisi Operasional dan Pengukuran Variabel Penelitian

\begin{tabular}{|l|l|c|c|c|}
\hline \multicolumn{1}{|c|}{ Variabel } & \multicolumn{1}{|c|}{ Definisi Operasional } & $\begin{array}{c}\text { Skala } \\
\text { Pengukuran }\end{array}$ & Ukuran & $\begin{array}{c}\text { Jumlah Item } \\
\text { Pernyataan }\end{array}$ \\
\hline $\begin{array}{l}\text { Nilai } \\
\text { Fungsional }\end{array}$ & $\begin{array}{l}\text { Nilai yang berasal dari } \\
\text { persepsi kualitas dan kinerja } \\
\text { suatu produk }\end{array}$ & $\begin{array}{c}\text { Peng } \text { et } \\
\text { al.,(2019) }\end{array}$ & $\begin{array}{c}\text { Likert } \\
(1-5)\end{array}$ & 4 item \\
\hline $\begin{array}{l}\text { Nilai } \\
\text { Emosional }\end{array}$ & $\begin{array}{l}\text { Nilai yang berasal dari } \\
\text { perasaan atau kondisi afektif } \\
\text { yang dihasilkaan oleh proses } \\
\text { pembelian suatu produk. }\end{array}$ & $\begin{array}{c}\text { Peng } \text { et } \\
\text { al.,(2019) }\end{array}$ & $\begin{array}{c}\text { Likert } \\
(1-5)\end{array}$ & 4 item \\
\hline $\begin{array}{l}\text { Tekanan } \\
\text { Waktu }\end{array}$ & $\begin{array}{l}\text { Perasaan subjektif dari urgensi } \\
\text { dan kecemasan yang dirasakan } \\
\text { konsumen ketika berbelanja }\end{array}$ & $\begin{array}{c}\text { Peng } \text { et } \\
\text { al.,(2019) }\end{array}$ & $\begin{array}{c}\text { Likert } \\
(1-5)\end{array}$ & 3 item \\
\hline Niat Beli & $\begin{array}{l}\text { Keiingian konsumen untuk } \\
\text { membeli suatu produk }\end{array}$ & $\begin{array}{c}\text { Peng } \text { et } \\
\text { al.,(2019) }\end{array}$ & $\begin{array}{c}\text { Likert } \\
(1-5)\end{array}$ & 4 item \\
\hline
\end{tabular}

\section{HASIL DAN PEMBAHASAN}

\section{a. Uji Validitas dan Reliabilitas}

Berdasarkan hasil uji validitas konvergen menggunakan analisis faktor konfirmatori dengan batasan minimum loading factor 0,50 dan uji reliabilitas berdasarkan nilai minimum Cronbach's Alpha 0,60. Dari 15 item butir item pernyataan, terdapat 1 item yang tidak valid yaitu item TW3 dan nilai Cronbach Alpha 0,692-0,910. Hasil uji validtas dan uji reliabilitas dapat dilihat pada Tabel 2.

Tabel 2

Hasil Pengujian Validitas dan Reliabilitas

\begin{tabular}{|c|c|c|}
\hline Item & Faktor Loading & Nilai Cronbach's Alpha (o) \\
\hline NE 1 & 0,743 & 0,910 \\
\hline
\end{tabular}




\begin{tabular}{|l|l|l|}
\hline NE 2 & 0,811 & \multirow{2}{*}{} \\
\hline NE 3 & 0,797 & \\
\hline NE 4 & 0,759 & \\
\hline NF 1 & 0,670 & \multirow{2}{*}{0,879} \\
\hline NF 2 & 0,852 & \\
\hline NF 3 & 0,841 & \multirow{2}{*}{0,692} \\
\hline NF 4 & 0,754 & \\
\hline TW 1 & 0,744 & \multirow{2}{*}{0,841} \\
\hline TW 2 & 0,849 & \\
\hline NB 1 & 0,588 & \\
\hline NB 2 & 0,780 & \\
\hline NB 3 & 0,570 & \\
\hline NB 4 & 0,686 & \\
\hline
\end{tabular}

Sumber: Diolah Tahun 2020

\section{b. Uji Ketepatan Model}

Ketepatan fungsi regresi dalam menaksir nilai aktual dapat diukur dari ketepatan model yang dilihat dari nilai koefisien determinasi $\left(\mathrm{R}^{2}\right)$, nilai statistik $\mathrm{F}$ dan nilai statistik $\mathrm{t}$. Hasil dari uji ketepatan model disajikan pada Tabel 3. Koefisien determinasi digunakan untuk menguji ketepatan model dari model regresi. Berdasarkan Tabel 3 diketahui bahwa nilai Adjusted $R^{2}$ nya adalah 0,598 , yang artinya 59,8 persen variasi dari variabel dependen yaitu niat beli dapat dijelaskan oleh variabel independen yaitu nilai fungsional dan nilai emosional sementara sisanya sebesar 40,2 persen dijelaskan oleh variabel-variabel lain di luar model.

Uji pengaruh simultan (F test) digunakan untuk mengetahui apakah variabel independen dalam penelitian ini adalah nilai fungsional dan nilai emosional secara bersamasama atau simultan mempengaruhi variabel dependen dalam penelitian ini adalah niat beli. Dari Tabel 3 menunjukkan bahwa nilai $F$ sebesar 111.947 signifikansi 0,000 dapat dinyatakan bahwa nilai fungsional dan nilai emosional berpengaruh secara bersama-sama pada niat beli.

Tabel 3

Hasil Pengujian Hipotesis 1 dan Hipotesis 2

\begin{tabular}{|c|c|c|c|c|c|c|c|c|}
\hline \multirow[t]{2}{*}{ Hipotesis } & \multirow{2}{*}{$\begin{array}{c}\text { Variabel } \\
\text { Independen }\end{array}$} & \multirow[t]{2}{*}{$\mathbf{R}^{2}$} & \multirow{2}{*}{$\begin{array}{l}\text { Adjusted } \\
\qquad \mathbf{R}^{\mathbf{2}}\end{array}$} & \multirow[t]{2}{*}{$\mathbf{F}$} & \multicolumn{3}{|c|}{$\begin{array}{c}\text { Variabel Dependen: } \\
\text { Niat Beli }\end{array}$} & \multirow[t]{2}{*}{ Hasil } \\
\hline & & & & & $\beta$ & $\mathbf{t}$ & Sig. & \\
\hline $\mathrm{H} 1$ & $\begin{array}{c}\text { Nilai } \\
\text { Fungsional }\end{array}$ & \multirow{2}{*}{0,604} & \multirow{2}{*}{0,598} & \multirow{2}{*}{$\begin{array}{c}111,947 \\
(0,000)\end{array}$} & 0,258 & 3,735 & 0,000 & Diterima \\
\hline $\mathrm{H} 2$ & $\begin{array}{c}\text { Nilai } \\
\text { Emosional }\end{array}$ & & & & 0,578 & 9,415 & 0,000 & Diterma \\
\hline
\end{tabular}

Ket. *Sig. $p<0,05$

Uji Parsial ( $\mathrm{t}$ test), digunakan untuk mengetahui pengaruh masing-masing variabel independen dalam penelitian ini adalah nilai fungsional dan nilai emosional pada variabel dependen dalam penelitian ini adalah niat beli. Berdasarkan Tabel 3 menunjukkan nilai $t$ dan signifikansi untuk masing-masing variabel adalah $\mathrm{t}=3,735$, Sig. $=0,000(\mathrm{p}<0,05)$ untuk variabel nilai fungsional, sementara untuk variabel nilai emosional $t=9,415$, Sig. $=0,000$ $(\mathrm{p}<0,05)$. 


\section{c. Hasil Pengujian Hipotesis dan Pembahasan}

Hipotesis 1 dalam penelitian ini menyatakan bahwa nilai fungsional berpengaruh positif pada niat beli. Pengujian hipotesis 1 dengan menggunakan analisis regresi berganda. Hasil pengujian hipotesis tersebut dapat dilihat pada Tabel 3. Dilihat dari koefisien $\beta$ dan signifikansi pada Tabel 3 hasilnya menunjukkan terdapat pengaruh yang positif dan signifikan $(\beta=0,258$, Sig. $=0,000)$, yang berati bahwa variabel nilai fungsional berpengaruh positif dan signifikan terhadap niat beli konsumen pada produk flash sale, sehingga dapat disimpulkan bahwa hipotesis 1 dalam penelitian ini diterima. Artinya semakin meningkat nilai fungsional maka akan meningkatkan niat beli konsumen pada produk flash sale. Temuan tersebut sesuai dengan hasil penelitian dari (Peng et al.,2019) menemukan bahwa nilai fungsional berpengaruh pada niat beli. Hal ini juga didukung oleh hasil penelitian Toufani et al., (2017) menyatakan bahwa variabel fungsional merupakan variabel yang paling berpengaruh terhadap niat beli. Hal ini membuktikan bahwa nilai fungsional merupakan salah satu variabel yang penting dalam belanja online yang dapat mempengaruhi niat beli konsumen. Jadi semakin tinggi nilai fungsional maka akan meningkatkan niat beli konsumen pada produk flash sale.

Hipotesis 2 dalam penelitian ini menyatakan bahwa nilai emosional berpengaruh pada niat beli. Pengujian hipotesis 2 dengan menggunakan analisis regresi berganda. Hasil pengujian hipotesis tersebut dapat dilihat pada Tabel 3. Dilihat dari koefisien $\beta$ dan signifikansi pada Tabel 3, hasilnya menunjukkan terdapat pengaruh yang positif dan signifikan $(\beta=0,578$, Sig. $=0,000)$, yang artinya nilai emosional berpengaruh positif dan signifikan pada niat beli sehingga dapat disimpulkan bahwa hipotesis 2 dalam penelitian ini diterima. Temuan tersebut sesuai dengan hasil penelitian dari Peng et al., (2019) yang menemukan bahwa nilai emosional berpengaruh pada niat beli. Dodd et al.,(1991) juga mengemukakan bahwa terdapat pengaruh positif antara nilai emosional dan niat beli konsumen. Hasil ini sesuai juga dengan hasil penelitian Asshidin et al., (2016) yang menyatakan bahwa nilai emosional merupakan salah satu prediktor dari niat beli. Hal ini menunjukkan bahwa semakin tinggi nilai emosional maka akan meningkatkan niat beli konsumen pada produk flash sale.

Tabel 3

Hasil Pengujian Hipotesis 3 dan Hipotesis 4

\begin{tabular}{|c|c|c|c|c|c|c|c|}
\hline \multirow{2}{*}{$\begin{array}{c}\text { Tahapa } \\
\text { n } \\
\text { Regresi }\end{array}$} & \multirow{2}{*}{$\begin{array}{c}\text { Variabel } \\
\text { Independen } \\
/ \\
\text { Pemoderasi } \\
\end{array}$} & \multicolumn{5}{|c|}{ Variabel Dependen : Niat Beli } & \multirow[b]{2}{*}{ Hasil } \\
\hline & & $\begin{array}{c}\text { Adjuste } \\
\text { d R }^{2}\end{array}$ & $\Delta \mathbf{R}^{2}$ & $\boldsymbol{\beta}$ & $\mathbf{t}$ & Sig. & \\
\hline \multicolumn{8}{|c|}{ Hipotesis 3} \\
\hline 1 & NF & 0,360 & - & 0,604 & 9,217 & 0,000 & \multirow{6}{*}{ Ditolak } \\
\hline \multirow{2}{*}{2} & $\mathrm{NF}$ & \multirow{2}{*}{0,438} & \multirow{2}{*}{0,077} & 0,486 & 6,563 & 0,000 & \\
\hline & TW & & & 0,273 & 4,618 & 0,000 & \\
\hline \multirow{3}{*}{3} & $\mathrm{NF}$ & \multirow{3}{*}{0,460} & \multirow{3}{*}{0,011} & 0,062 & 0,272 & 0,786 & \\
\hline & TW & & & $-0,237$ & $-0,897$ & 0,371 & \\
\hline & Interaksi & & & 0,133 & 1,983 & 0,049 & \\
\hline \multicolumn{8}{|c|}{ Hipotesis 4} \\
\hline 1 & $\mathrm{NE}$ & 0,563 & - & 0,714 & 13,894 & 0,000 & \multirow{6}{*}{ Ditolak } \\
\hline \multirow{2}{*}{2} & $\mathrm{NE}$ & \multirow{2}{*}{0,583} & \multirow{2}{*}{0,020} & 0,623 & 10,460 & 0,000 & \\
\hline & TW & & & 0,152 & 2,846 & 0,000 & \\
\hline \multirow{3}{*}{3} & $\mathrm{NE}$ & \multirow{3}{*}{0,563} & \multirow{3}{*}{0,038} & $-0,098$ &,- 517 & 0,606 & \\
\hline & TW & & & $-0,643$ & $-3,124$ & 0,002 & \\
\hline & Interaksi & & & 0,222 & 3,988 & 0,000 & \\
\hline
\end{tabular}

Ket. *Sig. $p<0,05$ 
Hipotesis 3 dalam penelitian ini menyatakan bahwa tekanan waktu memoderasi secara negatif hubungan nilai emosional pada niat beli. Jadi, semakin tinggi tekanan waktu, maka memperlemah hubungan nilai fungsional terhadap niat beli. Hasil pengujian hipotesis tersebut dapat dilihat pada Tabel 4. Berdasarkan Tabel 4 tersebut diketahui bahwa pada tahapan regresi pertama, nilai adjusted $\mathrm{R}^{2}$ adalah 0,360 dan mengalami peningkatan pada tahapan regresi kedua menjadi 0,438 . Kemudian pada tahapan regresi ketiga, nilai adjusted $\mathrm{R}^{2}$ juga mengalami peningkatan menjadi 0,460. Dengan melihat nilai koefisien $\beta$ dan signifikansi pada variabel interaksi nilai fungsional dan tekanan waktu, hasilnya menunjukkan nilai yang positif dan signifikan $(\beta=0,133 \mathrm{Sig} .=0,049)$. Berdasarkan nilai Adjusted $\mathrm{R}^{2}$ pada ketiga tahapan regresi serta nilai koefisien $\beta$ dan signifikansi pada variabel interaksi tersebut, maka dapat disimpulkan bahwa tekanan waktu memoderasi secara positif hubungan nilai fungsional pada niat beli yang artinya hipotesis 3 dalam penelitian ini ditolak. Jadi tekanan waktu memperkuat hubungan nilai fungsional terhadap niat beli. Jadi, semakin tinggi tekanan waktu maka memperkuat hubungan nilai fungsional terhadap niat beli konsumen pada produk flash sale. Hasil ini berbeda dengan hasil penelian Peng et al., (2019) yang menyatakan bahwa tekanan waktu terbukti memoderasi secara negatif hubungan nilai fungsional terhadap niat beli sehingga memperlemah hubungan antara nilai fungsional terhadap niat beli.

Hipotesis 4 dalam penelitian ini menyatakan bahwa tekanan waktu memoderasi secara negatif hubungan nilai emosional terhadap niat beli. Hasil pengujian hipotesis tersebut dapat dilihat pada Tabel 4. Berdasarkan Tabel 4 tersebut diketahui bahwa pada tahapan regresi pertama, nilai Adjusted $\mathrm{R}^{2}$ adalah 0,563 dan mengalami peningkatan pada tahapan regresi kedua menjadi 0,583 . Kemudian pada tahapan regresi ketiga, nilai adjusted $\mathrm{R}^{2}$ menjadi 0,563 . Dengan melihat nilai koefisien $\beta$ dan signifikansi pada variabel interaksi nilai emosional dan tekanan waktu, hasilnya menunjukkan pengaruh yang positif dan signifikan $(\beta=0,222 \mathrm{Sig}$. $=0,000)$. Berdasarkan nilai adjusted $\mathrm{R}^{2}$ pada ketiga tahapan regresi serta nilai koefisien $\beta$ dan signifikansi pada variabel interaksi tersebut, maka dapat disimpulkan bahwa tekanan waktu memoderasi secara positif hubungan nilai emosional pada niat beli yang artinya hipotesis 4 dalam penelitian ini ditolak. Jadi, semakin tinggi tekanan waktu, maka memperkuat hubungan nilai emosional terhadap niat beli konsumen pada produk flash sale. Hasil ini berbeda dengan hasil penelitian Peng et al., (2019) yang menyatakan bahwa tekanan waktu memoderasi secara negatif hubungan nilai emosional terhadap niat beli. Dimana semakin tinggi tekanan waktu maka memperlemah hubungan nilai emosional terhadap niat beli pada produk flash sale.

\section{E. KESIMPULAN}

Berdasarkan hasil penelitian menunjukan bahwa dari keempat hipotesis tersebut, hanya dua hipotesis yang diterima. Nilai fungsional dan nilai emosional terbukti berpengaruh positif dan signifikan terhadap niat beli konsumen pada produk flash sale. Sementara, tekanan waktu tidak terbukti memoderasi secara negatif hubungan nilai fungsional terhadap niat beli dan hubungan nilai emosional terhadap niat beli. Selain itu, hasil penelitian ini diharapkan dapat memberikan tambahan informasi dan bukti empiris bagi pengembangan literatur mengenai hubungan antara nilai fungsional dan nilai emosional terhadap niat beli konsumen terutama untuk produk flash sale. Selain itu, juga dapat memberikan masukan bagi situs belanja terutama yang menjual produk flash sale untuk meningkatkan promosi penjualan produk. Mengingat masih sangat sedikit penelitian yang menguji produk flash sale. Diharapkan kedepan untuk meneliti variabel lain terkait produk flash sale. Diharapkan bagi penelitian mendatang juga dapat menggunakan variabel lain yang dapat digunakan sebagai variabel moderasi atau variabel mediasi seperti keterlibatan produk dan kepercayaan. 


\section{F. DAFTAR PUSTAKA}

Asshidin, N.H.N., Abidin, N., \& Borhan B, H (2016), "Perceived quality and emotional value that influence consumer's purchase intention towards American and local products, “ Procedia Economic and Finance, Vol 35, 639-643.

Chen, C-F (2008), "Investigating structural relationships between service quality, perceived value, satisfaction, and behavioral intentions for air passengers: Evidence from Taiwan," Transportation Research Part A, Vol 42, 709-717.

Chen, C., \& Tsai, M. (2008), "Perceived value, satisfaction, and loyalty of TV travel product shopping : Involvement as a moderator," Tourism Management, Vol 29, 1166-1171.

Cialdini, R.B (2009), Influence: Science and Practice. Influence Science \& Practice.

Dodds, W. B., Monroe, K. B., Grewal, D., Dodds, W. B., Monroe, K. B., \& Grewal, D (1991), "Effects of price , brand , and store information on buyers 'product evaluations," Journal of Marketing Research, Vol 28 (3), 307-319.

Easwar, S dan Iyer (1989), "Unplanned purchasing: knowledge of shopping environment and time pressure," Journal of Retailing, Vol 65 (1) 40-57

Edward Shih-Tse Wang (2010), "Impact of Multiple Perceived Value on Consumers Brand Preference and Purchase Intention: A Case of Snack Foods, Journal of Services Marketing, Vol. 22 No. 7, 562-567.

Ettman, J. A. R. B. (1996).'When Time Is Money: Decision Behavior under Opportunity-Cost Time Pressure." Vol 66(2), 131-152.

Fishbein, M. and Ajzen, I. (1975), "Belief, Attitude, Intention and Behavior: An Introduction to Theory and Research," Addison-Wesley, Reading, MA.

Grewal, D., Roggeveen, A. L., Compeau, L. D., \& Levy, M (2012), "Retail value-based pricing strategies : new times, new technologies, new consumers," Journal of Retailing, 88(1), 16.

Hair, Jr., R.E. Anderson, R.L. Tatham, \& W.C. Black (2014), Multivariate Data Analysis A Global Perspective, $7^{\text {th }}$ edition, Upper Saddle River, New jersey: Pearson Education.Inc.

Hawkins, Delberts \& David Mothersbaugh. (2010), Consumer Behavior: Building Marketing Strategy, $11^{\text {th }}$ ed. New York: McGraw-Hill Companies, Inc.

Ho, C., \& Wu, T (2012), "Factors affecting intent to purchase virtual. International Journal of Electronic Business Management," Vol 10(3), 204-212.

Jang, S. S., \& Namkung, Y.(2009). "Perceived quality, emotions, and behavioral intentions: Application of an extended Mehrabian-Russell model to restaurants.," Journal of Business Research, Vol 62(4), 451-460.

Inman, J.J.,Peter, A.C.,Raghubir, P (1997)," Framing the deal: The role of restrictions in accentuating deal value, “ Journal of Consumer Research, Vol 24 (1) 68-79

Kannan, N., Babu, K., Hu,Y.J., \& Narasimhan, S (2016), "Social media, flash sales and the maker movement: An Empirical Analysis

Kim, H., Koh, J., \& Lee, H. L (2009), “Investgating The Intention Of Purchasing Digital Items In Virtual Communities," Association for Information Systems, Vol 48(6), 228-234.

Kocher, M. G., Pahlke, J., \& Trautmann, S. T., (2013), “Tempus fugit : time pressure in risky decisions," Management Science, Vol 59 (10), 2380-2391

Krishnan, B. C., Dutta, S., \& Jha, S. (2013), "Effectiveness of exaggerated advertised reference prices: the role of decision time pressure," Journal of Retailing, Vol 89(1), 105-113.

Morwitz, V.G. and Schmittlein, D. (1992), "Using segmentation to improve sales forecasts based on purchase intent: which 'intenders' actually buy?", Journal of Marketing Research, Vol. 29 No. 4, pp. 391-405.

Paola, M. De, \& Gioia, F (2016)," Who performs better under time pressure ? Results from a field experiment . Journal of Economic Psychology, Vol 53, 37-53. 
Peng, L., Zhang, W., Wang, X., \& Liang, S (2019), "Moderating effects of time pressure on the relationship between perceived value and purchase intention in social e-commerce sales promotion: considering the impact of product involvement," Information and Management, Vol 56(422), 317-328.

Riesz, P.C (1980),“A major price-perceived quality study reexamined, ”Journal of Marketing Research. Vol 17 (2) 259-262.

Saidani, B., Mustahid, M.S. dan Haro, A. (2017), "The influence of perceived quality, brand image, and emotional value towards purchase intention of consina backpack," Jurnal Riset Manajemen Sains Indonesia. Vol 8 (19), 1-19.

Schiffman, L \& Kanuk L.L (2016), Perilaku Konsumen, Edisi 7, Jakarta: Indeks.

Saqib, N. U., \& Chan, E. Y (2015),"Time pressure reverses risk preferences. Organizational Behavior and Human Decision Processes, Vol 130, 58-68.

Svenson, O., Maule, A.J., (1993), "Time pressure and stress in human judgment and decision making., Springer US.

Sweeney J.C dan Soutar G.N (2001), "Consumer perceived value: the development of a multiple item scale," Journal of Retailing, Vol 77 (2) 203-220

Toufani, S., Stanton, J.P dan Chikwede, T. (2017), "The important of aesthetics on customers's intention to purchase smartphone.," Marketing Intelligent and Planning Vol. 35 (3), 316338.

Vakeel, K.A., Sivakumar, K., Jayasimha, K.R \& Dey, S (2018), "Service failures after online flash sales : role of deal proneness , attribution , and emotion," Journal of Service Management, Vol 29 (2), 253-276. 